\title{
Preliminary validation of the Test of Object Relations in a sample of Croatian students
}

\author{
GREGOR ŽVELC and TIJANA BERLAFA
}

\begin{abstract}
The article describes preliminary validation of the Croatian version of the Test of Object Relations (TOR). The test was developed by G. Žvelc as a self-rating instrument for measuring the quality of object relations. The test measures three dimensions (Dependence, Alienation and Self-Absorption) and six sub-dimensions of object relations (Symbiotic Merging, Separation Anxiety, Narcissism, Egocentricity, Fear of Engulfment and Social Isolation). This test and Experiences in Close Relationship Scale were administered to a sample of 254 Croatian students from different faculties, of which 125 were males. Internal scale consistency is comparable to the results obtained from the Slovene sample. Principal components analysis supported the three main dimensions of object relations and five sub-dimensions. The results did not confirm Symbiotic Merging as a separate sub-dimension. Results of the principal components analysis suggest that the questionnaire in its present form includes items with low factor loadings and loadings on more than one dimension. The above findings suggest that the questionnaire can be shortened. This test correlates in a predictable way with attachment dimensions in adulthood. The main limitation of the preliminary study is a relatively small sample size. Further research on different samples is proposed, especially on a sample of psychiatric patients.
\end{abstract}

Key words: Test of Object Relations, object relations, attachment theory, object attachment, psychoanalytic research

Greenberg and Mitchell (1983) wrote that the term "object relations" refers to the individual's relations with other people, the individual's relations with internal object representations, as well as the interaction between the internal object world and the external object reality. The theory of object relations is not a uniform theory - it consists of contributions from different authors who developed their own theoretical models, sometimes quite independently from other authors.

The Test of Object Relations (TOR; Žvelc, 1998, 2007, $2008,2010 \mathrm{a}, 2010 \mathrm{~b})$ measures the quality of object relations in adulthood. The test was created on the basis of Loevinger's (1957) model of test construction and Jackson's (Jackson, 1970, 1971) sequential system of construction. Test construction and validation according to Loevinger's

Gregor Žvelc, Department of Psychology, Faculty of Arts, University of Ljubljana, Aškerčeva 2, 1000 Ljubljana, Slovenia, and Department of Psychology, Faculty of Mathematics, Natural Sciences and Informational Technologies, University of Primorska, Glagoljaška 8, 6000 Koper, Slovenia. E-mail: gregor.zvelc@guest.arnes.si (the address for correspondence);

Tijana Berlafa, psychologist, Osječka 8, 51000 Rijeka. model (1957) takes place in three phases: theoretical, internal-structural and external. With this test development strategy, each phase depends on the results of the previous phase.

In the theoretical-substantive development of the TOR, our task was first to develop a coherent theoretical model of object relations in adulthood. This resulted in the development of an integrative model of interpersonal relationship (Žvelc, 2007, 2010a, 2011). In this model, three main dimensions of object relations were described (dependence, alienation and self-absorption). Each of the dimensions in question is composed of two sub-dimensions describing different, albeit related aspects of the main dimension. Basic dimensions and sub-dimensions of object relations were derived from studying the works of different object relations theorists (Balint, 1985; Fairbairn, 1952, 1941/1986, 1943/1986; Greenberg \& Mitchell, 1983; Guntrip, 1968/1992; Kernberg, 1975, 1976, 1984; Kohut, 1971/1990, 1977; Mahler, Pine, \& Bergman, 1975; Winnicot, 1953/1986, 1960/1986). The above-mentioned dimensions were presented in most writings of object relations theorists, and are considered to be useful concepts in clinical practice (Žvelc, 2010a). The test is a self-rating questionnaire, which measures the dimensions and sub-dimensions of object relations (Figure 1). 


\begin{tabular}{lc}
\hline Dimension & Sub-dimensions \\
\hline Dependence & Symbiotic Merging \\
& Separation Anxiety \\
Alienation & Social Isolation \\
& Fear of Engulfment \\
Self-absorption & Narcissism \\
& Egocentrism \\
\hline
\end{tabular}

Figure 1. Dimensions and sub-dimensions of object relations. Adapted from "Object and subject relations in adulthood - Toward integrative model of interpersonal relationships" by G. Žvelc, 2010, Psychiatria Danubina, 22(4), p. 501.

Dependence dimension includes two sub-dimensions that can be seen as two perspectives of dependent, nonautonomous functioning (Žvelc, 2010b). Symbiotic Merging is a sub-dimension that refers to the weak differentiation between self and others, to merging and feelings of oneness with others or to desires and longings for establishing symbiotic relationships. Separation Anxiety, on the other hand, is a sub-dimension that indicates difficulty in tolerating separation from significant others and fear of abandonment.

Alienation as the second dimension of the questionnaire refers to avoidance, lack of contact with other people and withdrawal into one's own world. Other characteristics include a feeling of alienation, absence of intimate relationships, distrust and self-sufficiency. Alienation is comprised of the sub-dimension called Fear of Engulfment that refers to individuals who fear they would lose their own identity, individuality or freedom (i.e., they would be engulfed) in relationships with others. Fear of engulfment causes fear of intimate relationships - individuals who experience such fears want to be independent and therefore act counterdependently. Social Isolation as the second sub-dimension refers to avoidance and lack of relationship with others and withdrawal into one's own world. Alienation, a lack of intimate relationships, distrust, and self-sufficiency are typical for this dimension.

The Self-Absorption dimension describes individuals who have not managed to develop the capacity for reciprocity and manifest egocentric and narcissistic traits. Narcissism as one of two sub-dimensions describes an individual's grandiose and omnipotent experience of the self, while Egocentrism as the other sub-dimension refers to using and exploiting other people for one's own needs. Individuals with egocentric traits experience other people as a means of satisfying their own needs. Their relationships are based on manipulation and exploitation.

In the theoretical-substantive phase of development, 300 items reflecting six sub-dimensions of object relations were written (Žvelc, 1998). Items were evaluated in terms of their clarity, simplicity and intelligibility of content. The remain- ing 214 items underwent theoretical validation, wherein four psychotherapists trained in object relations psychotherapy evaluated each item and decided which sub-dimension of object relations it belongs to.

In internal-structural validation, we conducted a research on 118 university students. Our goal was to select items that would satisfy the theoretical, as well as psychometric criteria (Žvelc, 1998). Items showing a low correlation with their own scale $(<.20)$ and items which correlated more highly with an irrelevant scale were eliminated. These procedures helped to establish convergent and discriminant validity of the subscales (Jackson, 1970). After we had completed the above-described selection of items, we obtained 90 items satisfying both theoretical and psychometric criteria. Additional five items were added to distinguish social desirability of answers and random answering. The test takes 20-25 minutes to administer. It has satisfactory internal consistency and construct validity (Žvelc, 2007, 2008, 2011). The test is translated into English and Spanish language and was used in numerous studies in different countries (Barkhuizen, 2005; Dajčman, 2014; Kobal, 2002, 2008; Nettmann, 2013; Pahole, 2006; Pavšič Mrevlje, 2006; Restek-Petrović et al., 2012; Rogič Ožek, 2004; Štirn, 2002; Uršič, 2014; Žvelc, $2000,2008,2010$ b, 2011). It is used on both non-clinical and clinical population.

The aim of this preliminary research was to examine the basic measurement characteristics of the Croatian version of the TOR (Žvelc, 1998) on a population of Croatian students. We decided to focus on this issue due to the lack of instruments for determining the quality of object relations in adulthood in Croatia, as well as other countries.

\section{SUBJECTS AND METHOD}

\section{Participants}

Two self-report questionnaires were administered to a sample of 254 Croatian students. 125 participants were males and 129 females. Their age ranged from 19 to 35 years with an average of 20.8 years $(S D=2.37)$. The participating students studied at different faculties of University of Rijeka (Faculty of Humanities and Social Sciences, Medical Faculty, Faculty of Engineering, Faculty of Law, Faculty of Economics) and Faculty of Metallurgy, Zagreb.

\section{Instruments}

The Test of Object Relations. This instrument was developed by Žvelc (1998) as a self-rating instrument for measuring the quality of object relations. The test measures three dimensions (Dependence, Alienation and Self-Absorption) and six sub-dimensions of object relations (Symbiotic Merging, Separation Anxiety, Narcissism, Egocentricity, 
Fear of Engulfment and Social Isolation). The scale consists of 95 items. Each of the six sub-dimensions contains 15 items, and there is an additional 5-item validity scale for distinguishing social desirability of answers and random answering. Each item is rated on a 5-point Likert scale, from 1 (completely disagree) to 5 (completely agree). The instrument is presented in detail in the introductory part of this article.

The Croatian adaptation of the test took place in several phases. Firstly, the items from the TOR were translated from Slovene into Croatian language. While translating the test, we paid special attention to the meaning of individual items, as well as the dimension at which they were aimed. The first version of the translation was sent for review to the author. Certain items demanded further adaptation of the Croatian version to the Slovene version of the test. After the test had been corrected, we sent it for review to a Croatian psychologist. The psychologist sent us her comments, which were taken into consideration with the third review of the TOR. The next step was to send the test back to the author, who confirmed that the two versions were harmonised. Secondly, the test was given to a respondent who was not connected to the field of psychology in any way. We asked her to fill out the test and provide us with feedback on the clarity, unambiguous meaning and simplicity of items. Finally, the Croatian version of the TOR was proofread.

Experiences in Close Relationship Scale. This scale (Croatian adaptation and modification Kamenov \& Jelić, 2003) is a shortened version of the Experiences in Close Relationships Inventory (Brennan, Clark, \& Shaver, 1998). It measures two dimensions of attachment: Anxiety and Avoidance. Anxiety refers to fear of rejection or abandonment from other people. Avoidance refers to experiencing unpleasant feelings when being emotionally close to, or dependent on others. The revised version of the question- naire contains 18 items; each dimension contains 9 items (Kamenov \& Jelić, 2003). By means of factor analysis, it was determined that not only does the new version exhibit good construct validity; it also fully reflects the two-factor structure of the original scale. The two subscales are highly reliable (Cronbach alpha is .86 for Avoidance and .83 for Anxiety; Marušić, Kamenov, \& Jelić, 2011).

\section{Procedure}

Two questionnaires were administered to groups of students at each faculty. Groups differed in numbers and gender. All subjects gave informed consent and anonymity of subjects was preserved.

\section{RESULTS AND DISCUSSION}

The data was processed by means of the SPSS statistical software. Table 1 shows descriptive statistics of scales of the TOR. The results of Shapiro-Wilk test indicate that the data distribution in most scales does not differ from the normal one, except for the scales Fear of Engulfment, Social Isolation, Alienation and Validity Index. The skewness and kurtosis values are also relatively low $(<1)$.

\section{Internal consistency}

The reliability of sub-dimensions and dimensions in the Croatian version of the TOR (Table 1) show very good measurement characteristics of the translated version of the instrument, making it comparable with the results obtained from the Slovene sample (Žvelc, 2008, 2010b). The lowest reliability was observed with the sub-dimension Symbiotic Merging $(r=.73)$, where reliability was slightly

Table 1

Descriptive statistics, tests of normality and $\alpha$-coefficients of scales of the Test of Object Relations obtained on a sample of Croatian students $(N=254)$

\begin{tabular}{|c|c|c|c|c|c|c|c|c|c|}
\hline Dimension & $M$ & $S D$ & Min & Max & Skewness & Kurtosis & Shapiro- Wilk & $p$ & $\alpha$ \\
\hline DEP & 78.5 & 16.0 & 39 & 125 & -0.08 & -0.17 & .994 & .41 & .87 \\
\hline SM & 40.5 & 7.8 & 18 & 59 & -0.23 & -0.39 & .989 & .06 & .73 \\
\hline SA & 38.0 & 9.4 & 15 & 66 & 0.09 & -0.08 & .995 & .51 & .81 \\
\hline SAB & 73.7 & 16.6 & 33 & 116 & 0.18 & -0.34 & .992 & .16 & .89 \\
\hline $\mathrm{Na}$ & 37.6 & 9.8 & 17 & 63 & 0.17 & -0.26 & .991 & .10 & .84 \\
\hline $\mathrm{Eg}$ & 36.2 & 9.1 & 15 & 62 & 0.13 & -0.42 & .991 & .14 & .84 \\
\hline $\mathrm{AL}$ & 62.6 & 18.2 & 32 & 140 & 0.64 & 0.74 & .969 & .00 & .92 \\
\hline $\mathrm{FE}$ & 33.9 & 9.9 & 17 & 70 & 0.34 & -0.06 & .973 & .00 & .87 \\
\hline SI & 28.7 & 9.9 & 15 & 70 & 0.95 & 0.95 & .938 & .00 & .87 \\
\hline VI & 9.2 & 3.5 & 4 & 20 & 0.91 & 0.05 & .905 & .00 & .50 \\
\hline
\end{tabular}

Note. DEP = Dependence; $\mathrm{SM}=$ Symbiotic Merging; $\mathrm{SA}=$ Separation Anxiety; $\mathrm{SAB}=$ Self-absorption; $\mathrm{Na}=\mathrm{Narcissism} ; \mathrm{Eg}=\mathrm{Egocentrism} ; \mathrm{AL}=\mathrm{Aliena}-$ tion; FE = Fear of Engulfment; SI = Social Isolation; VI = Validity Index 
Table 2

Correlations between scales of the Test of Object Relations $(N=254)$

\begin{tabular}{|c|c|c|c|c|c|c|c|c|c|c|}
\hline Dimension & DEP & SM & SA & SAB & $\mathrm{Na}$ & $\mathrm{Eg}$ & $\mathrm{AL}$ & FE & SI & VI \\
\hline SM & $.91 * *$ & - & & & & & & & & \\
\hline SA & $.93 * *$ & $.69 * *$ & - & & & & & & & \\
\hline SAB & $.34 * *$ & $.38 * *$ & $.28 * *$ & - & & & & & & \\
\hline $\mathrm{Na}$ & $.16^{*}$ & $.24 * *$ & .08 & $.88 * *$ & - & & & & & \\
\hline $\mathrm{Eg}$ & $.45^{* *}$ & $.41^{* *}$ & $.42 * *$ & $.86^{* *}$ & $.55^{* *}$ & - & & & & \\
\hline $\mathrm{AL}$ & $.28 * *$ & $.30 * *$ & $.21 * *$ & $.53 * *$ & $.41 * *$ & $.53 * *$ & - & & & \\
\hline $\mathrm{FE}$ & $.22 *$ & $.25^{* *}$ & $.15^{*}$ & $.51 * *$ & $.40 * *$ & $.50 * *$ & $.92 * *$ & - & & \\
\hline SI & $.28 * *$ & $.29 * *$ & $.26^{* *}$ & $.46^{* *}$ & $.34 * *$ & $.48 * *$ & $.91 * *$ & $.68 * *$ & - & \\
\hline VI & .02 & .03 & -.01 & $.18^{* *}$ & $.12 *$ & $.22 * *$ & $.14^{*}$ & $.12 *$ & $.13^{*}$ & - \\
\hline
\end{tabular}

Note. DEP = Dependence; $\mathrm{SM}=$ Symbiotic Merging; $\mathrm{SA}=$ Separation Anxiety; $\mathrm{SAB}=$ Self-absorption; $\mathrm{Na}=\mathrm{Narcissism}$; Eg = Egocentrism; $\mathrm{AL}=\mathrm{Aliena}-$ tion; $\mathrm{FE}=$ Fear of Engulfment; $\mathrm{SI}=$ Social Isolation; VI = Validity Index. $* p<.05$. ** $p<.01$.

lower in comparison to the existing cases of research, in which reliability of the dimension amounted to .75 (Žvelc, 2008, 2010b). With the Croatian version of the test, four sub-dimensions (Egocentrism, Narcissism, Fear of Engulfment and Social Isolation) showed slightly higher reliability coefficient values when compared to the Slovene version (Žvelc, 2008, 2010b). All three higher-order dimensions exhibited high reliability coefficient values - Dependence had $\alpha$-coefficient value .87, Self-Absorption dimension .89 and in case of Alienation dimension, $\alpha$-coefficient value was 92 .

The lowest reliability was observed with the Validity Index (.50). The result did not surprise us as the scale comprises only five items. Furthermore, the index of validity also includes items detecting both random answering and socially desirable answers, which may have contributed to the low reliability of the scale.

From the correlations between the dimensions of the TOR (Table 2), we can observe that all of the correlations are statistically significant, except for the correlation between Separation Anxiety and Narcissism dimensions. The highest correlation within the dimensions of the TOR was found between Symbiotic Merging and Separation Anxiety dimensions, while the lowest statistically significant correlation was found between Separation Anxiety and Fear of Engulfment dimensions. Symbiotic Merging and Separation Anxiety dimensions showed a higher inter-correlation than correlations with other sub-dimensions. The same trend was observed with Narcissism and Egocentrism, and the Fear of Engulfment and Social Isolation pairs of sub-dimensions. These pairs of dimensions refer to the theoretically most correlated constructs (Žvelc, 2007, 2010a). The strength of correlations and their level were not dissimilar to the ones obtained by Žvelc (2007). That points to a similar structure of test results. Furthermore, Table 2 shows that higher-order dimensions are inter-correlated - the highest correlations were observed between Alienation and Self-Absorption dimensions, and the lowest between Alienation and Dependence dimensions.

\section{Principal components analysis}

We applied principal components analysis to investigate the internal structure of the instrument. Our aim was to explore if items of the test could be reduced to fewer dimensions of object relations. The value of Kaiser-Meyer-Olkin measure of sampling adequacy was .809 , while Bartlett's sphericity test showed statistical significance $\left(\chi^{2}=10841.323, p<.000\right)$. These values suggested that the data were adequate for principal components analysis. We performed Horn's parallel analysis, which suggested seven possible principal components. We first explored a six-components solution as we postulated existence of six separate scales, however only a five- and three-components solution provided meaningful interpretation. Five components accounted for $36.95 \%$ of the variance. We resorted to promax rotation as theoretically sub-dimensions of object relations are not meant to be independent (Žvelc, 1998, 2007, 2010a). Five components could be interpreted as five sub-dimensions of object relations (Separation Anxiety, Fear of Engulfment, Social Isolation, Narcissism and Egocentricity). The first component accounts for $16.96 \%$ of the variance and resembles Separation Anxiety sub-dimension and dimension Dependence. It includes mostly items from Separation Anxiety and eight items reflecting Symbiotic Merging. These sub-dimensions are closely related theoretically (Žvelc, 1998). The second component is consistent 
Table 3

Items with low $(<.40 ; \mathrm{LL})$ and theoretically incongruent (higher on irrelevant sub-dimension; TIL) loadings

\begin{tabular}{lll}
\hline \multirow{2}{*}{ Sub-dimension } & Items & \\
\cline { 2 - 3 } & LL & TIL \\
\hline SA & 27 & $24(\mathrm{Eg}), 37(\mathrm{Eg}), 86(\mathrm{SI}, \mathrm{Eg})$ \\
$\mathrm{SM}$ & 4,66 & $\begin{array}{l}14(\mathrm{Eg}), 18(\mathrm{FE}, \mathrm{SI}), 20(\mathrm{SA}), 28(\mathrm{SA}), \\
33(\mathrm{SA}), 38(\mathrm{SA}), 47(\mathrm{Eg}), 55(\mathrm{FE}, \mathrm{Eg}),\end{array}$ \\
& & $71(\mathrm{SA}), 82(\mathrm{SA}), 83(\mathrm{SA}), 92(\mathrm{SA}), 93(\mathrm{FE})$ \\
$\mathrm{FE}$ & 9,60 & $19(\mathrm{SI})$ \\
$\mathrm{SI}$ & & $59(\mathrm{FE})$ \\
$\mathrm{Na}$ & 8,61 & \\
Eg & 6,80 & $12(\mathrm{Na}), 25(\mathrm{Na}), 42(\mathrm{SA}), 43(\mathrm{Na}), 69(\mathrm{SA})$, \\
& & $95(\mathrm{Na})$
\end{tabular}

Note. Initials in the brackets indicate sub-dimensions on which the item loads higher than the relevant scale. $\mathrm{SA}=$ Separation Anxiety; $\mathrm{SM}=$ Symbiotic Merging; FE = Fear of Engulfment; $\mathrm{SI}=$ Social Isolation; $\mathrm{Na}=$ Narcissism; Eg = Egocentrism.

with Fear of Engulfment sub-dimension and the third with Social Isolation. These sub-dimensions are theoretically closely related to each other which is mirrored in research findings (some items from these sub-dimensions have factor loadings on both components). The fourth component corresponds to the sub-dimension of Narcissism and the fifth component to Egocentricity.

Theoretically, we predicted six sub-dimensions of object relations; however Symbiotic Merging as a separate sub-dimension was not supported. Results show that items reflecting Symbiotic Merging are connected to other subdimensions of object relations, especially Separation Anxiety (see Table 3 ). Table 3 shows items that have loadings higher on irrelevant sub-dimension and items with low $(<$ .40) loadings. Scale Egocentricity includes six items that have higher loadings on the irrelevant sub-dimensions. On the other hand, most items of Separation Anxiety, Fear of Engulfment, Social Isolation and Narcissism reflect the subdimensions for which they had been written.

We also explored a three-component solution, which was supported by scree plot. The first three components obtained in our study accounted for $31 \%$ of variance. We used promax rotation to increase interpretability of results. The three components are saturated with items describing three main dimensions of object relations - Alienation, Dependence and Self-Absorption. The first component we interpreted as Alienation dimension. It is saturated with items describing Social Isolation and Fear of Engulfment scale. The second component is saturated with items related to Separation Anxiety and Symbiotic Merging. It could be interpreted as Dependence. The third component we interpreted as Self-Absorption dimension. It is saturated with items from Narcissism and Egocentricity scales. The three component solution supports three main dimensions of object relations, which is congruent with the theoretical model (Žvelc, 2007, 2010a) and Slovene research findings (Žvelc, 2007).

The results of component analysis suggest that the TOR can be substantially shortened. Some items have low factor loadings and some items have higher factor loadings on theoretically unjustified sub-dimensions. The next level of analysis included only those items with component loadings $>.50$. We also excluded items with component loadings $>$ .50 on more than one component or loadings with theoretically unjustified sub-dimension. Scree plot suggested five components accounting for $47.17 \%$ of variance. Table 4 shows factor loadings of items on five components which could be interpreted as five sub-dimensions of the TOR: (1) Social Isolation, (2) Fear of Engulfment, (3) Narcissism, (4) Separation Anxiety and (5) Egocentrism. Results show that shorter version of the TOR includes items that show good content differentiation between sub-dimensions of object relations. All items also reflect the scales for which they had been written.

Table 4

Principal components analysis performed on the shortened version of the Test of Object Relations

\begin{tabular}{rrllc}
\hline N. & Scale & Contents of the item & 1 & 2 \\
\hline 5 & SI & I have the feeling that nobody likes me. & .65 & .64 \\
7 & SI & Contacts with other people are not important to me. & .69 & .58 \\
26 & SI & I am not close to anyone. & .58 & .60 \\
35 & SI & I don't need other people. & .69 \\
51 & SI & I can't rely on anyone but myself. & .66 \\
62 & SI & I am mistrustful towards other people. & .73 \\
63 & SI & I have no one in my life on whom I can rely in difficult moments. & .70 \\
68 & SI & Other people seem so distant to me. &
\end{tabular}




\begin{tabular}{|c|c|c|c|c|c|c|c|}
\hline N. & Scale & Contents of the item & 1 & 2 & 3 & 4 & 5 \\
\hline 11 & FE & $\begin{array}{l}\text { I don't want to have a permanent partner because that would take away my } \\
\text { freedom. }\end{array}$ & & .73 & & & \\
\hline 23 & $\mathrm{FE}$ & $\begin{array}{l}\text { I refuse to become attached to other people because I don't want to lose my } \\
\text { freedom. }\end{array}$ & & .75 & & & \\
\hline 31 & $\mathrm{FE}$ & $\begin{array}{l}\text { I feel threatened when another person tries to establish a more intimate } \\
\text { relationship with me. }\end{array}$ & & .58 & & & \\
\hline 39 & $\mathrm{FE}$ & Sometimes I am afraid of another person getting too close to me. & & .67 & & & \\
\hline 48 & FE & My relationships are brief with no strings attached. & & .61 & & & \\
\hline 54 & $\mathrm{FE}$ & Sometimes I fear that another person will get overly attached to me. & & .73 & & & \\
\hline 56 & $\mathrm{FE}$ & $\begin{array}{l}\text { When a relationship with another person involves too much commitment, } \\
\text { I withdraw. }\end{array}$ & & .73 & & & \\
\hline 64 & $\mathrm{FE}$ & If I get too close to another person, I become afraid of losing myself. & & .58 & & & \\
\hline 74 & $\mathrm{FE}$ & $\begin{array}{l}\text { I would like to escape from a relationship that is becoming more and more } \\
\text { intimate. }\end{array}$ & & .68 & & & \\
\hline 2 & $\mathrm{Na}$ & I admire myself very much. & & & .65 & & \\
\hline 21 & $\mathrm{Na}$ & I am going to achieve more in life than other people. & & & .59 & & \\
\hline 29 & $\mathrm{Na}$ & Other people are fascinated by me. & & & .63 & & \\
\hline 34 & $\mathrm{Na}$ & I am better looking than other people. & & & .72 & & \\
\hline 36 & $\mathrm{Na}$ & I am worth more than other people. & & & .71 & & \\
\hline 45 & $\mathrm{Na}$ & Sometimes I feel as if I am almighty & & & .55 & & \\
\hline 53 & $\mathrm{Na}$ & Sometimes I feel so strong that I think nothing bad can happen to me. & & & .55 & & \\
\hline 72 & $\mathrm{Na}$ & I want to be perfect. & & & .50 & & \\
\hline 77 & $\mathrm{Na}$ & I believe I am truly special. & & & .70 & & \\
\hline 89 & $\mathrm{Na}$ & I believe as I was born to do great things. & & & .72 & & \\
\hline 13 & SA & $\begin{array}{l}\text { I am distressed if I have to take leave of a person who I feel close to, } \\
\text { even if only for a short time. }\end{array}$ & & & & .57 & \\
\hline 40 & SA & I feel bad if the person I love leaves me by myself. & & & & .65 & \\
\hline 50 & SA & I often think of the danger of losing the person I feel very close to. & & & & .66 & \\
\hline 52 & SA & It is difficult for me to cope with every separation from the person I love & & & & .74 & \\
\hline 65 & SA & $\begin{array}{l}\text { If the person I am very attached to has to leave for a while, I take an object } \\
\text { belonging to him/her to feel better. }\end{array}$ & & & & .53 & \\
\hline 67 & SA & Sometimes I fear that one of the people I am close to might die. & & & & .60 & \\
\hline 73 & SA & In a relationship, I try to chain the partner to myself. & & & & .50 & \\
\hline 76 & SA & When I go to bed at night, I want to have something with me to protect me. & & & & .66 & \\
\hline 79 & SA & When I go on a trip, I miss my family a lot. & & & & .62 & \\
\hline 10 & $\mathrm{Eg}$ & In a relationship I expect my partner to always accommodate to me. & & & & & 67 \\
\hline 30 & $\mathrm{Eg}$ & I feel bad if the person I love does something that goes against my wishes. & & & & & .67 \\
\hline 32 & $\mathrm{Eg}$ & When I am in relationship, I want to control my partner. & & & & & .60 \\
\hline 84 & $\mathrm{Eg}$ & I want other people to be the way I want them to be. & & & & & .67 \\
\hline 88 & Eg & In a relationship, I do not allow my partner the things I allow myself. & & & & & .60 \\
\hline \multirow[t]{4}{*}{90} & $\mathrm{Eg}$ & $\begin{array}{l}\text { In a relationship I become very angry when my partner doesn't act as } \\
\text { I want him/her to. }\end{array}$ & & & & & .73 \\
\hline & & Eigenvalues & 8.76 & 4.40 & 3.76 & 2.11 & 1.73 \\
\hline & & Explained variance (\%) & 19.90 & 9.99 & 8.54 & 4.79 & 3.94 \\
\hline & & Cumulative variance (\%) & 19.90 & 29.90 & 38.44 & 43.24 & 47.17 \\
\hline
\end{tabular}

Note. Absolute loadings less than .50 are censored. N. = number of the item; SA = Separation Anxiety; SM = Symbiotic Merging; FE = Fear of Engulfment SI $=$ Social Isolation; $\mathrm{Na}=$ Narcissism $; \mathrm{Eg}=$ Egocentrism . 
Correlations between the dimensions of the Test of Object Relations and attachment dimensions measured by Experiences in Close Relationship Scale $(N=254)$

\begin{tabular}{|c|c|c|c|c|c|c|c|c|c|c|}
\hline Dimension & DEP & SM & SA & SAB & $\mathrm{Na}$ & $\mathrm{Eg}$ & $\mathrm{AL}$ & FE & SI & VI \\
\hline Anxiety & $.60 * *$ & $.50 * *$ & $.61 * *$ & $.32 * *$ & .10 & $.49 * *$ & $.33 * *$ & $.27 * *$ & $.34 * *$ & -.07 \\
\hline Avoidance & .08 & .08 & .08 & $.33^{* *}$ & $.24 * *$ & $.37 * *$ & $.63^{* *}$ & $.57 * *$ & $.59 * *$ & $.29 * *$ \\
\hline
\end{tabular}

Note. DEP = Dependence; $\mathrm{SM}=$ Symbiotic Merging; $\mathrm{SA}=$ Separation Anxiety; $\mathrm{SAB}=$ Self-Absorption; Na = Narcissism; Eg = Egocentrism; $\mathrm{AL}=\mathrm{Aliena}-$ tion; FE = Fear of Engulfment; SI = Social Isolation; VI = Validity Index.

$* p<.05 . * * p<.01$.

\section{Convergent validity}

While examining the convergent validity of the TOR, we determined the theoretically expected correlations between object relations and attachment dimensions in adulthood. If we look at the results in Table 5, we can observe that both dimensions of Experiences in Close Relationship Scale (Anxiety and Avoidance) show statistically significant correlations with all three higher-order dimensions of the TOR, i.e., Dependence, Self-Absorption and Alienation. With regard to the level of correlations, dimension of Anxiety showed the highest correlation with Dependence, a higher-order dimension, while Avoidance correlated the highest with Alienation. Correlations correspond to the theoretical assumptions of the TOR, since the dimension of Dependence corresponds to Anxiety, while Alienation corresponds to Avoidance (Žvelc, 2010b). Results confirm expected correlations between object relations and dimensions of attachment styles.

\section{GENERAL DISCUSSION AND CONCLUSION}

TOR is a self-report questionnaire, which measures the dimensions and sub-dimensions of object relations. The aim of the research was to examine the measurement characteristics of the Croatian version of the TOR. The internal scale consistency of the Croatian version of the test is very good and comparable to the results obtained from the Slovene sample (Žvelc, 2007, 2010b). Namely, the majority of dimensions and sub-dimensions showed $\alpha$-coefficient greater than .80. The level and strength of correlations were similar to the ones observed in the Slovene sample, which points to a similar structure of correlations between dimensions and sub-dimensions of the test.

We explored the internal structure of the instrument with the principal components analysis. Five-component solution provided the most meaningful interpretation and supported the five sub-dimensions of object relations: Separation Anxiety, Fear of Engulfment, Social Isolation, Narcissism, and Egocentricity. However, the results did not confirm Symbiotic Merging as a separate sub-dimension. The majority of items on this scale had high loadings on the sub-dimension of Separation Anxiety, with some items having high loadings on Egocentricity and Fear of Engulfment. The latter finding suggests that merging with others and difficulty of differentiation between self and others is a part of other sub-dimensions of object relations. We further tested a three-component solution that supported three main dimensions of object relations: Dependence, Self-Absorption, and Alienation.

Results of the principal components analysis also suggest that the questionnaire in its present form includes some items with low factor loadings and loadings on more than one dimension. Five components also explain only $36.95 \%$ of variance. The questionnaire also includes 95 items and is not very economical. For the purposes of further analysis, we therefore excluded items with low component loadings and loadings on more than one component from the questionnaire. The shorter form of the questionnaire thus only included 44 items. We performed a principal components analysis of the shorter form and found that five components explained $47.17 \%$ of the variance. Results also indicate good differentiation between five sub-dimensions of object relations. However, the shorter form does not include the scale Symbiotic Merging. In future research, we propose further testing of both 95 -item and 44-item versions of the test on different samples, including clinical samples. Future research may show whether Symbiotic Merging could be used as a separate scale or as a part of other sub-dimensions and dimensions of object relations.

The external validity was examined by correlations with attachment styles in adulthood. Results showed a statistically significant correlation between object relations dimensions and the basic dimensions of attachment styles in adulthood, thus confirming our assumptions that the dimension of Dependence corresponds to Anxiety, while dimension of Alienation corresponds to Avoidance (Žvelc, 2010b).

The main limitation of the preliminary study at hand is a relatively small sample size. Psychometric characteristics were examined on a sample of students. In the future, the psychometric characteristics of the test should be examined on larger samples and also on other populations, including clinical populations. 


\section{REFERENCES}

Balint, M. (1985). Osnovna greška. Terapijski aspekti regresije [The basic fault. Therapeutic aspects of regression]. Zagreb: Naprijed.

Barkhuizen, J. (2005). An exploration of the intrapsychic development and personality structure of serial killers through the use of psychometric testing (Unpublished master's thesis). University of Pretoria, Faculty of Humanities.

Brennan, K. A., Clark, C. L., \& Shaver, P. R. (1998). Selfreport measurement of adult romantic attachment: An integrative overview. In J. A. Simpson \& W. S. Rholes (Eds.), Attachment theory and close relationships (pp. 46-76). New York: Guilford Press.

Dajčman, S. (2014). Nezvestoba v povezavi z intimnostjo in teorijo objektnih odnosov [Infidelity in relation to intimacy and object relations theory] (Unpublished master's thesis). University of Maribor, Department for Psychology.

Fairbairn, W. R. D. (1952). Psychoanalytic studies of the personality. New York: Routledge.

Fairbairn, W. R. D. (1986). A revised psychopathology of the psychoses and psychoneuroses. In P. Buckley (Ed.), Essential papers on object relations (pp. 71-101). New York: New York University Press. (Original work published in 1941)

Fairbairn, W. R. D. (1986). The repression and the return of bad objects (with special reference to the 'war neuroses'). In P. Buckley (Ed.), Essential papers on object relations (pp. 102-126). New York: New York University Press. (Original work published in 1943)

Greenberg, J. R., \& Mitchell, S. A. (1983). Object relations in psychoanalytic theory. Cambridge: Harvard University Press.

Guntrip, H. (1992). Schizoid phenomena, object relations and the self. London: Karnac books. (Original work published in 1968)

Jackson, D. N. (1970). A sequential system for personality scale development. In C. D. Spielberger (Ed.), Current topics in clinical and community psychology. Vol. 2. (pp. 61-96). New York: Academic Press.

Jackson (1971). The dynamics of structured personality tests. Psychological Review, 78(3), 229-248.

Kamenov, Ž., \& Jelić, M. (2003). Validacija instrumenta za mjerenje privrženosti u različitim vrstama bliskih odnosa: Modifikacija Brennanova Inventara iskustava u bliskim vezama [Validation of instrument for measuring attachment in different close relationships: Modification of Brennan's Experiences in Close Relationships Inventory]. Suvremena psihologija, 6, 73-91.

Kernberg, O. F. (1975). Borderline conditions and pathological narcissism. Northvale, NJ: Jason Aronson.
Kernberg, O. F. (1976). Object-relations theory and clinical psychoanalysis. Northvale, NJ: Jason Aronson.

Kernberg, O. F. (1984). Severe personality disorders. Psychotherapeutic Strategies. New Haven: Yale University Press.

Kobal, L. (2002). Evalvacija psihoterapevtskih premikov pri prostovoljcih iz vidika teorije objektnih odnosov [Evaluation of the therapeutic shifts on volunteers from the point of the object relations theory]. Psihološka obzorja [Horizons of Psychology], 11(4), 103-122.

Kobal, L. (2008). Navezanost in proces separacije-individualizacije pri mladih odraslih $\mathrm{v}$ vlogi prostovoljcev na področju psihosocialne pomoči [Attachment and process of separation-individuation of volunteers in psychosocial help]. Psihološka obzorja [Horizons of Psychology], 17(1), 57-72.

Kohut, H. (1990). Analiza sebstva [Analysis of the self]. Zagreb: Naprijed. (Original work published in 1971)

Kohut, H. (1977). The restoration of the self. Madison, CT: International Universities Press.

Loevinger, J. (1957). Objective tests as instruments of psychological theory. Psychological Reports, 3, 635-694.

Mahler, M. S., Pine, F., \& Bergman, A. (1975). The psychological birth of the human infant. London: Hutchinson.

Marušić, I., Kamenov, Ž., \& Jelić, M. (2011). Personality and attachment to friends. Društvena istraživanja: Journal of General Social Issues, 4, 1119-1137.

Nettmann, R. W. (2013). Moving towards, against and away from people: The relationship between Karen Horney's interpersonal trends and the enneagram (Unpublished master's thesis). University of South Africa.

Pahole, M. (2006). Osebnostne dimenzije, slogi (tipi) navezanosti ter njihova generacijska skladnost pri osebah $z$ motnjami hranjenja [Personality dimensions, attachments styles and their generational congruency on the sample of patients with eating disorders]. (Unpublished doctoral thesis). University of Ljubljana, Department of Psychology.

Pavšič Mrevlje, T. (2006). Materinstvo, objektni odnosi in trajanje dojenja [Motherhood, object relations and breastfeeding duration]. Psihološka obzorja [Horizons of Psychology], 15(4), 67-84.

Restek-Petrović, B., Mihanović, M., Grah, M., Molnar, S., Bogović, A., Agius. M.,... Vrbek, P. (2012). Early intervention program for psychotic disorders at the Psychiatry hospital 'Sveti Ivan'. Psychiatria Danubina, 24(3), 323-332.

Rogič Ožek, S. (2004). Razvojni proces separacije in individualizacije pri gibalno oviranih osebah [Developmental process of separation-individuation and movement disabled persons] (Unpublished master's thesis). University of Ljubljana, Department of Psychology. 
Štirn, M. (2002). Oris osebnostnih značilnosti storilcev spolnih deliktov [Personality characteristics of perpetrators of sexual delicts] (Unpublished master's thesis). University of Ljubljana, Department of Psychology.

Uršič, T. (2014). Primerjava navezanosti, objektnih odnosov in procesa separacije-individualizacije pri edincih in osebah z brati ali s sestrami [Comparison of attachment, object relations and the process of separationindividuation among only children and individuals with siblings] (Unpublished master's thesis). University of Maribor, Department for Psychology.

Winnicot, D. W. (1986). Transitional objects and transitional phenomena. In P. Buckley, (Ed.), Essential Papers on Object Relations (str. 254-272). New York: New York University Press. (Original work published in 1953)

Winnicot, D. W. (1986). The theory of the parent-infant relationship. In P. Buckley (Ed.), Essential Papers on Object Relations (pp. 233-254). New York: New York University press. (Original work published in 1960)

Žvelc, G. (1998). Razvoj testa objektnih odnosov [Development of the Test of Object Relations]. Psihološka obzorja [Horizons of Psychology], 7(3), 51-67.
Žvelc, G. (2000). Značilnosti objektnih odnosov oseb, ki so odvisne od drog [Characteristics of object relations among drug addicts]. Odvisnosti [Addictions], 1(1-2), 21-27.

Žvelc, G. (2007). Razvoj integrativnega modela diadnih odnosov [Development of the integrative model of dyadic relations] (Unpublished doctoral thesis). University of Ljubljana, Department of Psychology.

Žvelc, G. (2008). Test of object relations. Instructions for use [Unpublished manuscript]. Ljubljana: Institute for Integrative Psychotherapy and Counseling.

Žvelc, G. (2010a). Object and subject relations in adulthood - Toward integrative model of interpersonal relationships. Psychiatria Danubina, 22(4), 498-508.

Žvelc, G. (2010b). Object relations and attachment styles in adulthood. Psihološka obzorja [Horizons of Psychology], 19(2), 5-18.

Žvelc, G. (2011). Razvojne teorije v psihoterapiji. Integrativni model medosebnih odnosov [Developmental theories in psychotherapy. Integrative model of interpersonal relationships]. Ljubljana: Institute IPSA. 
